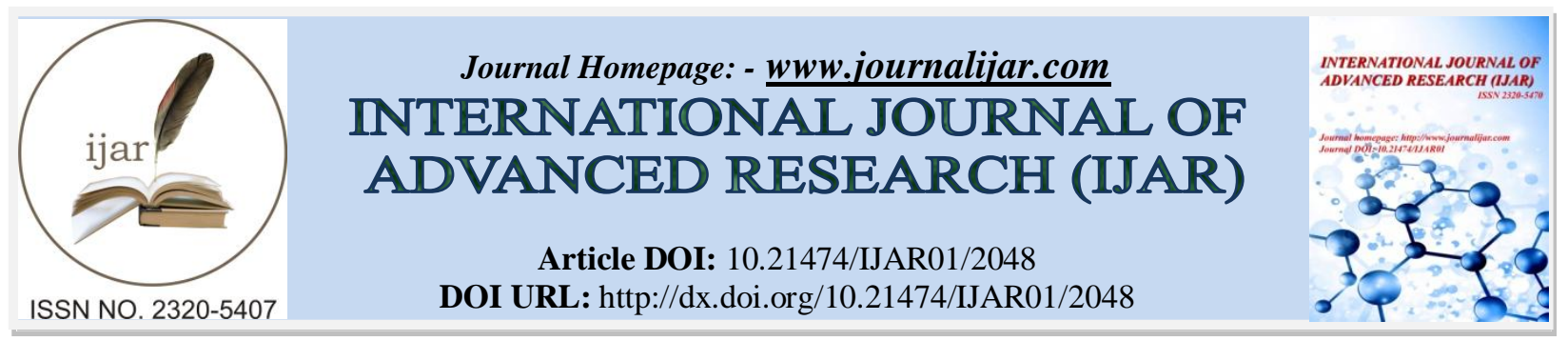

RESEARCH ARTICLE

\title{
WOMEN EMPOWERMENT OF POLITICAL PARTCIPATION IN INDIA.
}

\section{Dr. B. Prabhakararao.}

Academic Consultant, Dept. of Political Science \& Public Administration, Vikrama Simhapuri University, Nellore,Andhra Pradesh, India.

\section{Manuscript Info}

Manuscript History

Received: 20 September 2016

Final Accepted: 22 October 2016

Published: November 2016

\section{Abstract}

Political participation of women is of enormous use for planners and policy makers which help them to evolve better schemes and programs. Women participation in national level politics brings viewpoints which are essential for a holistic development of the society. The quantitative data on women participation is easy to measure and India has a long history of recording gender statistics for political participation. The challenge is to measure the actual participation of women and to filter out the problem of proxy participation which may be prevalent at the grass root level. Efforts are being undertaken to devise measures which would give a true picture of women's participation in national level politics.

Copy Right, IJAR, 2016,. All rights reserved.

\section{Introduction:-}

Democracy is a system which in Abraham Lincolns words, is a government of the people, by the people and for the people. While most of the democracies have given a system which has government elected by all the sections of societies, it is debatable whether the government comprises of all the diverse sections and importantly whether the government works for all the people of the democracy. In this context, the problem of low participation of women is of special concern for democracies and without changing that true democracy can never be achieved. Women's participation in decision-making is essential for women's interests to be incorporated into governance. It has been widely experienced that governance structures which do not provide for adequate participation of women, often suffer from states interventions which are neither inclusive nor democratic. Including women, in national governments is an essential step towards creating gender equal opportunities and gender sensitive policies. Since women have different needs and perspectives on social and political issues, it is important to involve women in governments to incorporate all of the societal viewpoints in policy and decision-making processes. Women are actively involved in household and community work and hence well aware of real issues faced by common people. This gives them insight and perspective which can be instrumental in sustainable overall development.

The presence of women in national government serves as an encouragement for other women to enter diverse professions and leads to breaking stereotypes of women's roles in society and public space. People had gained confidence in women as good public administrators and local government representatives after seeing women making a positive difference in other people's life. The society acknowledges the sincerity and commitment of women to their duties and their resistance to criminalization of politics.

The measurement of women political participation is essential to identify the need of policy intervention to improve the same. India had understood the need to record gender statistics on political participation since its independence.

Corresponding Author:- Dr. B. Prabhakararao.

Address:- Academic Consultant, Dept. of Political Science \& Public Administration, Vikrama Simhapuri 
The process of capturing women participation at the national politics is an evolving area and efforts are being done to improve the present infrastructure.

\section{Women participation in indian politics:-}

The status of women in India has seen many ups and downs since ancient times - from at par status in ancient history to be in veils (Parda System) during the Medieval period. In the post independent India, the status of women regained its strength and has been on a rise ever since. Women in post independent India have been participating in almost all types of economic activities, day-to-day household chores, voting for better governance and also in active politics. India has elected a woman prime minister, Indira Gandhi, and a woman president, Pratibha Patil. In the present central government, women comprise 7 out or 27 roughly quarter of the Indian cabinet with portfolios like external affairs, commerce and human resource development.

\section{Women Reservation Bill:-}

Post Gandhi, India experienced centralization of planning which resulted in higher inequality in political decision making at the various levels. While Government was deeply concerned of issues of gender equality, women were not always a part of such decision making. Although, India has seen women participating in politics as the longest serving Prime minister, as chief ministers of various states, members in national parliament and state legislative assemblies in large numbers, In order to enable better women participation in active politics, authorities had been trying to put in reservation for women but have not been successful in true terms due to non-support from some of the regional parties.

Back in history, one of the prominent member of freedom struggle, Sarojini Naidu rejected reservation for women, citing that women are not week, timid, meek. She claimed that the demand for granting preferential treatment to women is an admission on her part of her inferiority and there has been no need for such a thing in India as the women have always been by the side of men. The issue of women's reservation again came to limelight in 1973 with voices recommending reservation for women in at least one third of the seats and eventually statutory women's panchayats at the village level were recommended to take care of the neglect of women in rural development programs through $73^{\text {rd }} \& 74^{\text {th }}$ constitutional amendments in 1993 . Women's Reservation Bill or the Constitution $\left(108^{\text {th }}\right.$ Amendment) Bill, is a pending bill in India which proposes to reserve 33 per cent of all seats in the Lower house of Parliament of India, and in Measurement of Women's Political Participation at the all levels.

All state legislative assemblies for women. The seats to be reserved in rotation will be determined by draw of lots in such a way that a seat shall be reserved only once in three consecutive general elections. Women's Reservation Bill, was passed in Rajya Sabha on March 9, 2010 But Lok Sabha could not clear the bill due to resistance of some regional parties on certain provisions of the bill.

\section{Current measurement framework:-}

Women Representation among Elected Representatives As per the data from ECI, out of the total 4896 MLAs across the country, only 418 or $9 \%$ are women. Among MPs, Lok Sabha has 65 (12.15\% of 543 MPs) and Rajya Sabha has $10 \%$ or 23 (10\% of 233 MPs) women MPs. Among State assemblies, West Bengal 34 (out of 294 MLAs), Bihar 34 (out of 243 MLAs) and Andhra Pradesh 14 (out of 175 MLAs) have the maximum no of women MLAs followed by Uttar Pradesh with 32 women out of 403 MLAs and Rajasthan with 28 women out of 200 MLAs In terms of percentage, among state assemblies, the highest percentage of Women MLAs is from Bihar with $14 \%$ (34 out of 243 MLAs) followed by Rajasthan with 14\% (28 out of 200 MLAs) women votes and West Bengal with $12 \%$ (34 out of 294 MLAs).

In Lok Sabha elected by men 484MPs out of 543( 88/) and Rajya Sabha elected by men 210 out of 233(85) and also men MLA s elected by States of Uttar Pradesh 371 out of 403( 92\%), Maharashtra 277out of 288( 96\%), West Bengal 260 out of 294(78\%), Andhra Pradesh 161 out of 175 (92/), Bihar 209 out 243 ( $86 \%$ ), Tamil Nadu 217 out of 234( 93\%), Madhya Pradesh 205 out of 230(89\% ) and Gujarat 166 out of 182 (91\%), Karnataka 221 out of 224( $99 \%$ ), Rajasthan 172 out of 200( 86\%), Odisha 140 out of 147 ( $95 \%$ ) and Kerala 133 out of 140 (95). 
The first aspect we looked at was the extent to which women were elected in state assemblies across the country. Out of a total of 4,120 MLAs in 29 states and two union territories, there were a total of 280 women under 7 per cent of all MLAs compared to about 12.15 per cent women MPs in Lok Sabha.

All states could have been given to women nominal representation. As well as West Bengal has the highest percentage of women MLAs in the country (nearly 12 per cent) in a 294 member assembly. A region-wise look at the data throws up some surprises. Some states has no representation of women MLAs, see that, Arunachal Pradesh, Mizoram, Nagaland, Manipur and Assam.

The nature of women's representation seems to be qualitatively different at the various levels of government. The Lok Sabha has seen an increasing trend in the percentage of women MPs (currently over 9 per cent), while the representation at the state level is under 7 per cent. There is a need to take up deeper analysis of this important aspect of our democratic system.

\section{Introduction to Indian Electoral System:-}

India is the largest democracy in the world with a three layer governance structure: central government, state government and city/village government. The election to all these three is done by an independent body of Election Commission which is constituted separately at state and central level. At the national level, the head of government, prime minister, is elected by the members of Lok Sabha, lower house of the parliament of India. All members of Lok Sabha except two, who can be nominated by president of India, are directly elected through general elections which take place every five years, by universal adult suffrage. Unlike most of the other democracies of the world, India gave women voting right since the first election. Members of Rajya Sabha, upper house of Indian parliament, are elected by an Electoral college comprising of Members of Lok Sabha, elected members of the legislative assemblies of states and Union Territories of India. Similar structure is in place in various states of India with two bodies called Vidhan Sabha and Vidhan Parishad. Data of successive central and state elections show that Indian democracy is truly representative of women when it comes to their participation in elections but it significantly lacks women participation as legislature and executive.

\section{Electoral Statistics in India:-}

The Election Commission prepares, maintains and periodically updates the Electoral Roll, which shows who is entitled to vote, supervises the nomination of candidates, registers political parties, monitors the election campaign, including candidates funding. It also facilitates the coverage of the election process by the media, organizes the polling booths where voting takes place, and looks after the counting of votes and the declaration of results. All this is done to ensure that elections can take place in an orderly and fair manner. All the statistics for the elections is primarily maintained by the Election Commission with information on both the voter participation as well as the information on elected representatives. The electoral rolls in India are compiled based on a four stage classification. The entire country has been divided into 543 parliamentary constituencies. Each parliamentary constituency has several assembly constituencies in it. An assembly constituency is further divided into Wards. Each Ward has multiple Poll stations (PS) which are practically smallest manageable unit for conducting voting in that area. The information on voting pattern is accumulated at the polling station level with a field that includes gender information. Extensive data has been captured $16^{\text {th }}$ election which has been made public through digitalization. This allows the government to identify political participation of women in elections at the level of polling station which typically is of the order of 1000 voters. 
Table 1:- Shows the statistics of the voting percentage of women across different states in the recently held Lok Sabha elections (.2014).

\begin{tabular}{|l|c|c|c|}
\hline \multicolumn{1}{|c|}{ State } & Women Voters & Total & Percentage \\
\hline Andhra Pradesh & 23899017 & 48467721 & 49.31 \\
\hline Bihar & 17124395 & 35892459 & 47.71 \\
\hline Kerala & 9283321 & 17987124 & 51.61 \\
\hline Karnataka & 14876307 & 31053583 & 47.91 \\
\hline Madhya Pradesh & 22046720 & 48740403 & 45.23 \\
\hline Rajastan & 12440783 & 27133776 & 45.85 \\
\hline Tamilanadu & 20331223 & 40644282 & 50.00 \\
\hline Uttara Pradesh & 36081818 & 81118615 & 44.48 \\
\hline West Bengal & 24704436 & 51662564 & 47.82 \\
\hline Total (India) & 260192272 & 554175255 & 46.95 \\
\hline
\end{tabular}

(Central Election Commission of India.)

The women Voters are 47 percent of Total Voters in india,but they have no equal opportunity to the Political representation in our country.Its bad situation to the Indian Democratic System.

\section{Political Participation of Women:-}

Political participation of women can be measured in three different dimensions: their participation as a voter, their participation as an elected representative and their participation in the actual decision making process. The first of these two dimensions have been measured and reported by the Election Commission from the first election which was held in 1952 with few exceptions. The information on the women participation as a voter is recorded at a booth level which is the smallest possible entity in Indian electoral system.

With the electoral reforms that have taken place which include the recording of elections at sensitive places, information on women participation can be relied upon with a high degree of confidence. This information is not only helpful for the electoral process but can also be used by the policymakers to identify areas with lesser women participation and take remedial actions. As an example, government can open a girls school where the difference between men voting percentage and women voting percentage is more than $20 \%$. The second aspect of women becoming elected representative is also recorded at all the levels governments'. While India has a good record of women holding all the important posts in the country, the overall participation of women in politics is not very satisfactory.

Table 2:- Measurement of Women's Political Participation at the National 1 Level: (2014)

\begin{tabular}{|l|c|c|}
\hline \multicolumn{1}{|c|}{ State } & Lok Sabha & Vidhan Sabha \\
\hline Andhra Pradesh & $7.00 \%$ & $11.90 \%$ \\
\hline Assam & $14.29 \%$ & $14.81 \%$ \\
\hline Biha & $7.50 \%$ & $11.11 \%$ \\
\hline Chhatisgarh & $9.09 \%$ & $2.50 \%$ \\
\hline Goa & $0.00 \%$ & $6.59 \%$ \\
\hline Gujarat & $15.38 \%$ & $10.00 \%$ \\
\hline Haryana & $0.00 \%$ & $4.41 \%$ \\
\hline Himachal Pradesh & $0.00 \%$ & $3.45 \%$ \\
\hline Jammu \& Kashmir & $16.67 \%$ & $9.88 \%$ \\
\hline Jharkhand & $0.00 \%$ & $1.33 \%$ \\
\hline Karnataka & $3.57 \%$ & $5.00 \%$ \\
\hline Kerala & $5.00 \%$ & $13.48 \%$ \\
\hline Madhya Pradesh & $17.24 \%$ & $3.82 \%$ \\
\hline Maharashtra & $10.42 \%$ & $4.76 \%$ \\
\hline Odisha & $9.52 \%$ & $11.97 \%$ \\
\hline Punjab & $7.69 \%$ & $14.00 \%$ \\
\hline Rajasthan & $4.00 \%$ & $7.26 \%$ \\
\hline Tamil Nadu & $10.26 \%$ & $8.33 \%$ \\
\hline Tripura & $0.00 \%$ & $8.93 \%$ \\
\hline Uttar Pradesh & $16.25 \%$ & $7.14 \%$ \\
\hline Uttarakhand & $20.00 \%$ & $11.56 \%$ \\
\hline West Bengal & $28.57 \%$ & \\
\hline
\end{tabular}


(Central Election Commission of India.)

Commission launched a nation-wide pilot scheme in 2013-14 to establish the availability of desired data from identifiable sources with a view to study the need, financial implications and data sources.

Women participating in politics have a better understanding of women based issues and their awareness about the know-hows of government functioning render better solutions to the society in terms of bring about gender equity in the country. Once the qualitative data on women participation in politics is captured and analysed properly, the planners may give shape to more programmes on women empowerment to enhance the radiating effects of women empowerment.

\section{Challenges in measuring women political participation:-}

The measurement of women participation in politics based on voting percentage and election to legislature is relatively easy. The challenge is to estimate the actual participation of women in the decision making process and Awareness programs and increase in female education is now taking care of such happenings and women active participation is on an increase.

\section{Conclusion:-}

India has a rich history of measuring political participation of women since its independence. The decentralization of governance which is taking place for last two decades has increased the importance of measuring participation of women in decision making. Proper gender budgeting has already been worked out for inclusive growth of women $\&$ girls by ear-marking one third budget for the women in all the schemes. The Indian Government has a lot of emphasis on utilizing real time data for measuring different social indicators and using them for policy intervention. With more responsive data on women participation, better gender budget initiatives aim to move the country towards a gender equal society.

\section{References:-}

1. Rangrajan, C Report of the National Statistical Commission 2001: Ministry of Statistics and Programme Implementation.

2. Election Commission of India Election Statistics Pocket Book 2014: Election Commission of India.

3. Arun. Rashmi Role of Women in Panchayati Raj 1996: The Administrator

4. Thakur, Minni Women Empowerment through Panchayati Raj 2010: Concept Publishing House.

5. Pai, S Women and Panchayati Raj, The Law, Programmes and Practices: Journal of Rural Development.

6. Census Report 2011.

7. Vibuthipatel. Getting a Foot Hold in politics women in Political Decision Making Process,Social action Vol.65,no.1. Jan-March, 2005. p.p.40.

8. Narayana Jaya Prakash, Sheth Alternative to the Government Bill for Women s Reservation, Manushi,No.116,2000.pp7 